\title{
Carbon Footprint of Polycrystalline Photovoltaic Systems
}

\author{
Nikolaos Stylos , Christopher Koroneos*, \\ Unit of Environmental Science and Technology, National Technical University of Athens 9, Heroon Polytechniou Street, 15773 Zographou \\ Campus, Greece
}

*Corresponding author (koroneos@ chemeng.ntua.gr)

\begin{abstract}
The environmental and energy parameters of Photovoltaic (PV) systems play a very important role when compared to conventional power systems. In the present paper, a typical PV-system is analyzed to its elements and an assessment of the material and energy requirements during the production procedures is attempted. A Life Cycle Analysis (LCA) is being performed on the production system of photovoltaics. Energy and environmental analyses are extended to the production of the primary energy carriers. This allows having a complete picture of the life cycle of all the PVcomponents described in the present study. Four different scenarios are examined in detail providing every possible aspect of scientific interest involving polycrystalline PV systems. In order to obtain concrete results from this study, the specific working tool used is the Eco-Indicator '95 (1999) as being reliable and widely applied and accepted within LCA community. A process that relates inventory information with relevant concerns about natural resource usage and potential effects of environmental loadings is attempted. Large-scale PV-systems have many advantages in comparison with a conventional power system (e.g. diesel power station) in electricity production. As a matter of fact, PV-systems become part of the environment and the ecosystems from the moment of their installation. Carbon Footprints of various PV-systems scenarios are greatly smaller than that of a diesel power station operation. Further technological improvements in PV module production and in the manufacture of Balance-of-System components, as well as extended use of renewable energy resources as primary energy resources could make Carbon Footprint of PV systems even smaller. Extended operational period of time (O.P.T.) of PV-systems determined by system reliability should be given special attention, because it can dramatically mitigate energy resources and raw materials exploitation.
\end{abstract}

Keywords poly-silicon solar cells; photovoltaic-systems; Carbon Footprint, Greenhouse Gas 


\section{Introduction}

Photovoltaic systems convert light energy directly into electricity providing an interesting bundle of abundant energy source and at the same time environmental preservation, for the good of humanity and our planet (Pacca et al., 2007). Modern solar photovoltaic technology of the last decade is expected to resolve world energy sufficiency and environmental issues due to definite advantages of PV systems (Varun et al., 2009). Complicated PV systems provide electricity for pumping water, powering communications equipment, lighting homes and running appliances. In an extensive use of this technology, it is possible to produce a great amount of electricity through large-scale PV systems (Peng et al., 2013).

A grid-connected large-scale PV system consists of the photovoltaic modules, inverters (with all the necessary electronic components), batteries for the autonomy of the system, and other components such as cables, support structure and foundations (see Fig. 1) (Bernal-Agustín and Dufo-López, 2006).

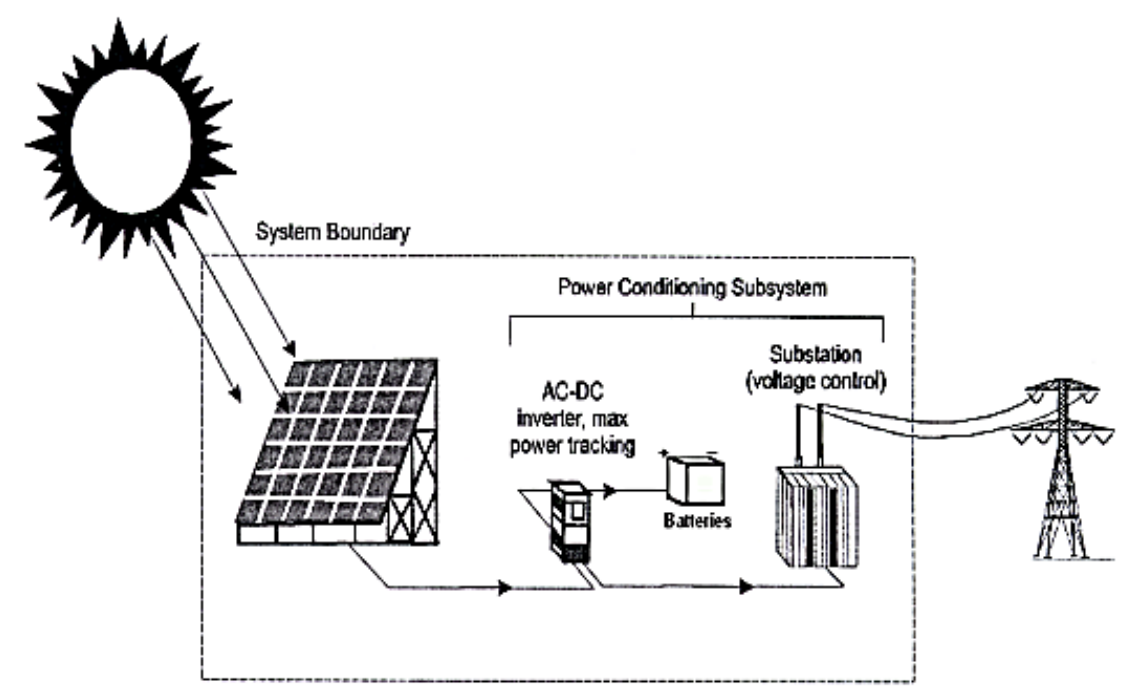

Fig.1. A large-scale grid-connected PV system schematic.

Photovoltaic modules consist of a number of solar cells relevant to the module area. The most important part of a solar cell is the semiconducting layers, where the electron current is created. There are a number of different materials suitable for manufacturing these semiconducting layers, and each has benefits and drawbacks. There is no ideal material for all types of cells and applications. The main types of solar cells are (Peng et al., 2013; Şengül and Theis, 2011):

1) Polycrystalline silicon cells (poly-Si, also called semi- or multicrystalline silicon)

2) Amorphous silicon cells (a-Si)

3) Cadmium Telluride cells (CdTe) 
In the current study, the life cycles of Polycrystalline silicon solar cell modules are analyzed, due to the advantages they present (Swanson, 2006). The most important advantage is that silicon is so readily abundant, since it is actually the second most abundant element in the Earth's crust-second only to oxygen. Many research institutions and manufacturers have an extensive research program in the area of Polycrystalline silicon solar cells. Their main objective is to make solar photovoltaic technology a beneficial solution for producing electricity (Raugei et al., 2007b; Jungbluth, 2005; Pacca et al., 2007).

\section{Materials and Methods}

\subsection{System definition}

A system is defined as a collection of materially and energetically connected operations (e.g., manufacturing processes, transport process, or fuel extraction process) which perform some defined function (de Haes et al., 1999).

In the present analysis the basic elements of the PV-system (see Fig.2) are the PV-modules, the inverters, the batteries and the steel foundations. PV-modules, which are the main PV-system's components, are fully analyzed to their materials and full inputs-outputs analyses have been implemented (GaBi Software, 2011). The term "various materials" in Fig.2 defines materials like aluminum, steel, copper, zinc and plastics, which are parts of the inverters, batteries and ECCS steel foundations.

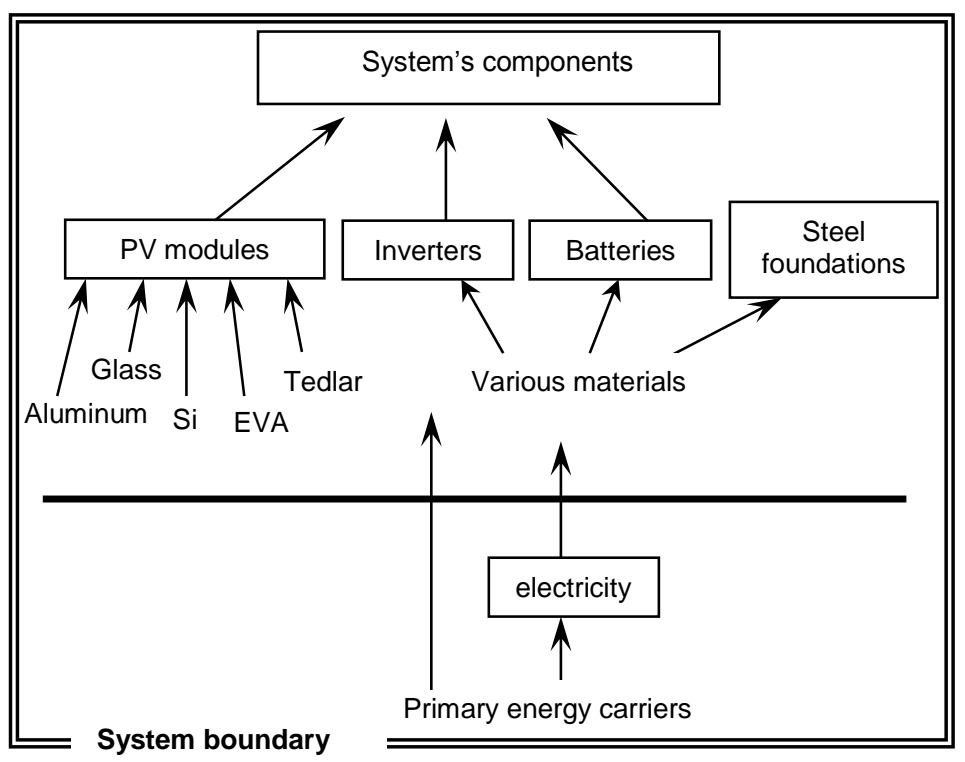

Fig.2. Basic elements of the grid-connected PV-system with energy storage.

\subsection{Life cycle inventory}

The life cycle of a Polycrystalline silicon PV module starts with the mining and refining of silica (quartz) (Stoppato, 2008; Raugei et al., 2007a). Silica is reduced with the use of carbon and the 
reduction step is either followed or preceded by a purification step. The resulting high purity silicon is melted and cast into blocks of Polycrystalline silicon. The blocks are portioned into ingots (lump of metal, cast in a mould), which are subsequently sliced into wafers. The wafers are processed into solar cells by etching, texture, formation of the emitter layer, application of back surface layer and contacts, passiveness and antireflective coating. The solar cells are tested, interconnected and subsequently encapsulated and framed into modules (Aulich and Schulze, 2002; Jungbluth et al., 2009).

At this point, it is crucial to note that the modes of transportation of raw materials that are necessary for the production of PV-module components (aluminum, glass, EVA, Tedlar, Si), taking into account travel distances to Nisyros island have been included in the inventories (Ecoinvent, 2011; GaBi Software, 2011). Same procedure has also been followed for the BOS-components (GaBi Software, 2011; Du Pont, 2013; Franklin Associates, 2010). In more detail, raw materials and necessary chemical compounds for the production of PV-modules have been exported from China to Japan, where production processes of the assumed modules take place. The delivery of PV raw materials to the japanese manufacturer has been made by cargo ship to cover a distance of 2,100 km, and another 300 $\mathrm{km}$ have been covered by road transport using a 40 tonnes truck. Then, PV-modules have been exported from Japan to Greece travelling 9,400 km by cargo ship. On the other hand, inverters, batteries and steel foundations are imported from Germany to Greece assuming road transport covering a $1,650 \mathrm{~km}$ distance by a 40 tonnes truck. All PV-system components have been transhipped to a freighter travelling $470 \mathrm{~km}$ from port of Piraeus to the island of Nisyros, where the assembly procedures of PV-systems take place.

The module fabrication processes diagram is shown on Fig.3. In this Figure the flow charts of the basic PV-module elements are included (Jungbluth, 2005). The polycrystalline solar modules manufacturing flow chart is a conjunction of studies stemming from the same database, thus ensuring reliability of inventory data (Ecoinvent, 2011). 


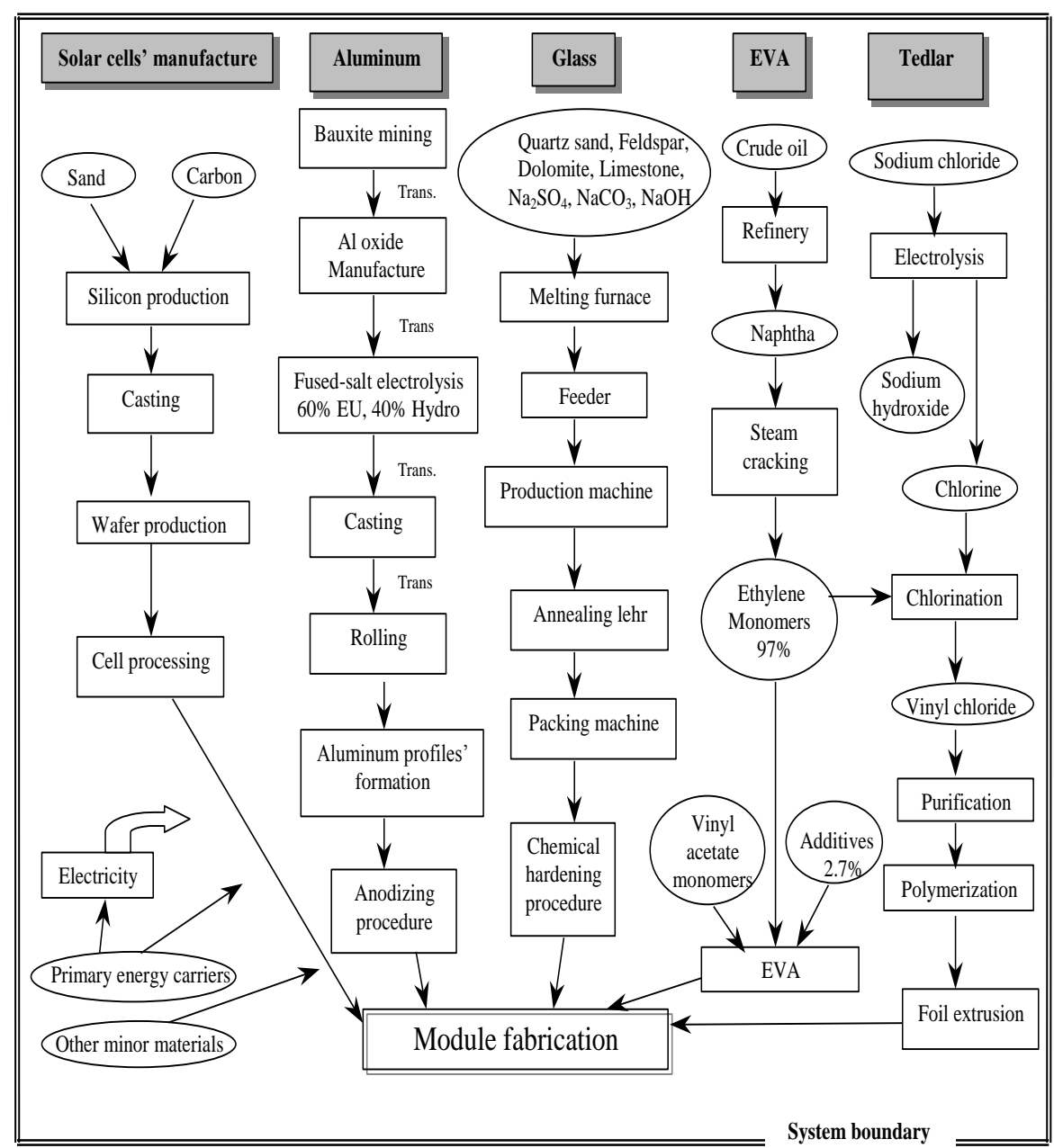

Fig.3. The system boundaries of energy, material and emissions flows.

The rest of the system's components other than PV-modules, namely inverters, batteries and Steel foundations, have been included in the evaluations of energy and materials requirements, as well as calculations of emissions in order to secure a complete overview of system's carbon footprint (Hischier et al., 2010; Mason et al. 2006).

In this study, four discerned cases are examined, which represent the present and future of PVtechnology: the base case, the improved case, the forward case and an application based to the KC-65T PV-module, which is a product of Kyocera Corporation (2013). Table 1 summarizes the most important tasks, which determine the technological cases.

The base case is chosen in such a way that it represents a good estimate of the present state of production technology and environmental control measures (Stoppato, 2008). The improved case is defined as the technology, which has been already reached and will be commercially available widely within next couple of years. The forward case represents an optimistic view on production technology available within the next 5 years (Swanson, 2006). Finally, KC-65T case is an application of a PV- 
module, which is already in the market. Thus, comparisons can be made among case scenarios and some useful conclusions can be drawn.

The process steps (Sherwani et al., 2010; Fthenakis et al., 2008) involved in the manufacturing of PV-modules are summarized on Table 1, while a short description of them follows:

(a) Silica is reduced to silicon by carbon in the form of charcoal, cokes, low ash coal and wood scrap.

(b) Production of high purity silicon is realized through the UCC-process, which is a silicon purification process based on fluidized-bed technology.

(c) Casting process, in which high purity silicon feedstock is converted into large blocks of Polycrystalline Si.

(d) The wafers are cut from the block in squares of $10 \times 10,12.5 \times 12.5$ or $15 \times 15 \mathrm{~cm}^{2}$ and thickness that varies from 156 to $250 \mu \mathrm{m}$ using state-of-the-art technological capabilities.

(e) The n-type emitter layer is formed in the wafer, usually by way of diffusion of phosphorus atoms, with the process taking place at temperatures of $850-900^{\circ} \mathrm{C}$ and the exceeding phosphorus pentoxide $\left(\mathrm{P}_{2} \mathrm{O}_{5}\right)$ is removed using hydrogen fluoride.

(f) In the metallization step, contacts are applied by screen printing. A uniform layer of an aluminum and silver containing paste is first screen printed on the backside of the cell, which provides a Back Surface Field (BSF).

(g) In the passiveness process hydrogen atoms created in plasma, diffuse into the wafer to inactivate recombination centers.

(h) The front surface is yet another facilitator of recombination processes. Usage of a layer of silicon nitride has yet another advantage, since it can also act as an antireflective coating (ARC).

(i) After cell processing the solar cells are tested. The yield of solar cell production is estimated at $95 \%$, i.e. $5 \%$ of the tested cells are rejected. The test procedure involves a production test (e.g. structure \& electrical performance test) and a reliability test (e.g. thermal cycle, heat, mechanical $\&$ static load, and robustness tests).

(j) Subsequently, the remaining cells are encapsulated into a module. The modulation process is similar for the four cases and only module size and other process parameters vary. The tested cells are laid out in a module matrix and interconnected in four series using tin-coated copper strips.

(k) The final step is the embedding of the cell matrix in Ethylene-Vinyl Acetate (EVA) copolymer foil. Then lamination takes place at $120-150^{\circ} \mathrm{C}$ and the edges of the module are sealed with a polysulphide elastomer and the modules are washed and dried. Finally a polyester junction box is attached and the module is framed with an aluminum frame. 
Table 1

The most important tasks for module fabrication (Peng et al., 2013; Stoppato, 2008).

\begin{tabular}{|c|c|c|c|c|c|}
\hline \multirow{2}{*}{$\frac{\text { Process step }}{\text { Silica reduction }}$} & parameter & Base case & Improved case & Forward case & KC65T case \\
\hline & $\begin{array}{l}\text { process } \\
\text { Process yield }(\%)\end{array}$ & $\begin{array}{l}\text { Arc furnace } \\
85 \\
\end{array}$ & $\begin{array}{l}\text { Arc furnace } \\
90 \\
\end{array}$ & $\begin{array}{l}\text { Arc furnace } \\
95 \\
\end{array}$ & $\begin{array}{l}\text { Arc furnace } \\
85 \\
\end{array}$ \\
\hline Production & $\begin{array}{l}\text { Process } \\
\text { Process yield }(\%)\end{array}$ & $\begin{array}{c}\text { UCC } \\
96 \\
\end{array}$ & $\begin{array}{c}\text { UCC } \\
98 \\
\end{array}$ & $\begin{array}{c}\text { UCC } \\
98 \\
\end{array}$ & $\begin{array}{c}\text { UCC } \\
96 \\
\end{array}$ \\
\hline Casting / portioning & $\begin{array}{l}\text { Casting method } \\
\text { Contouring losses }(\%)\end{array}$ & $\begin{array}{c}\text { Conventional } \\
\text { casting } \\
12 \\
\end{array}$ & $\begin{array}{c}\text { Improved } \\
\text { convent. casting } \\
11 \\
\end{array}$ & $\begin{array}{l}\text { Electromagnetic } \\
\text { casting } \\
6 \\
\end{array}$ & $\begin{array}{c}\text { Conventional } \\
\text { casting } \\
12 \\
\end{array}$ \\
\hline Wafering & $\begin{array}{l}\text { Wafer size }\left(\mathrm{cm}^{2}\right) \\
\text { Wafer thickness }(\mu \mathrm{m}) \\
\text { Wafering loss }(\mu \mathrm{m}) \\
\text { Sawing damage etchant }\end{array}$ & $\begin{array}{c}10 \times 10 \\
180 \\
180\end{array}$ & $\begin{array}{c}12.5 \times 12.5 \\
135 \\
135\end{array}$ & $\begin{array}{c}15 \times 15 \\
100 \\
100\end{array}$ & $\begin{array}{c}10.2 \times 10.05 \\
200 \\
200\end{array}$ \\
\hline Etching / texturing & Texturing & $\mathrm{NaOH}$ & $\mathrm{KOH}$ & $\begin{array}{l}\mathrm{NaOH} \\
\mathrm{NaOH} \\
\end{array}$ & $\mathrm{NaOH}$ \\
\hline \multirow[t]{2}{*}{ Emitter formation } & $\begin{array}{l}\text { Doping } \\
\text { Emitter back etch } \\
\text { Edge preparation }\end{array}$ & $\begin{array}{c}\mathrm{POCl}_{3} \text { in diffusion } \\
\text { oven } \\
- \\
\mathrm{CF}_{4} \text { plasma } \\
\end{array}$ & $\begin{array}{c}\mathrm{POCl}_{3} \text { in diffusion } \\
\text { oven } \\
\mathrm{HF} / \mathrm{HNO}_{3} \\
\mathrm{CF}_{4} \text { plasma } \\
\end{array}$ & $\begin{array}{c}\text { Screen printed } \mathrm{P} \text { in } \\
\text { IR oven } \\
- \\
\text { Polishing } \\
\end{array}$ & $\begin{array}{c}\mathrm{POCl}_{3} \text { in diffusion } \\
\text { oven } \\
- \\
\mathrm{CF}_{4} \text { plasma } \\
\end{array}$ \\
\hline & $\begin{array}{l}\text { Back contact layer } \\
\text { Back contact layer thickness }(\mu \mathrm{m}) \\
\text { Back side coverage factor }(\%) \\
\text { Front side contact } \\
\text { Front contact line width }(\mu \mathrm{m}) \\
\text { Front contact thickness }(\mu \mathrm{m})\end{array}$ & $\begin{array}{c}\text { Screen-printed Al } \\
\text { / Ag } \\
15 \\
100 \\
\text { Screen-printed Ag } \\
90 \\
10\end{array}$ & $\begin{array}{c}\text { Screen-printed Al } \\
\text { / Ag } \\
10 \\
100 \\
\text { Screen-printed Ag } \\
60 \\
15\end{array}$ & $\begin{array}{l}\text { Screen-printed Al } \\
20 \\
10 \\
\text { Screen-printed Ag } \\
40 \\
20\end{array}$ & $\begin{array}{c}\text { Screen-printed Al } \\
\text { / Ag } \\
15 \\
100 \\
\text { Screen-printed Ag } \\
90 \\
10\end{array}$ \\
\hline & Front side metal coverage $(\%)$ & 10 & 7 & 6 & 10 \\
\hline Passivation & $\begin{array}{l}\text { Bulk passivation / surface } \\
\text { passivation }\end{array}$ & PECVD of $\mathrm{Si}_{3} \mathrm{~N}_{4}$ & PECVD of $\mathrm{Si}_{3} \mathrm{~N}_{4}$ & - & PECVD of $\mathrm{Si}_{3} \mathrm{~N}_{4}$ \\
\hline $\begin{array}{l}\text { Antireflective } \\
\text { coating }\end{array}$ & & $\begin{array}{c}\text { in passivation } \\
\text { process }\end{array}$ & $\begin{array}{c}\text { in passivation } \\
\text { process }\end{array}$ & CVD of $\mathrm{TiO}_{2}$ & $\begin{array}{c}\text { in passivation } \\
\text { process }\end{array}$ \\
\hline Electr. Testing & Yield $(\%)$ & 95 & 95 & 95 & 95 \\
\hline \multirow[t]{2}{*}{ Module production } & $\begin{array}{l}\text { Cells/module } \\
\text { Glass sheet thickness }(\mathrm{mm}) \\
\text { EVA foil thickness }(\mathrm{mm}) \\
\text { Tedlar/Al/Tedlar thickness }(\mu \mathrm{m})\end{array}$ & $\begin{array}{c}36 \\
3 \\
2 \times 0.5\end{array}$ & $\begin{array}{c}36 \\
3 \\
2 \times 0.5\end{array}$ & $\begin{array}{c}40 \\
3 \\
2 \times 0.25\end{array}$ & $\begin{array}{c}36 \\
3 \\
2 \times 0.5\end{array}$ \\
\hline & Module size (total) $\left(\mathrm{m}^{2}\right)$ & $\begin{array}{l}125 \\
0.45 \\
\end{array}$ & $\begin{array}{l}125 \\
0.65 \\
\end{array}$ & $\begin{array}{c}125 \\
1 \\
\end{array}$ & $\begin{array}{c}125 \\
0.494 \\
\end{array}$ \\
\hline Module testing & Yield $(\%)$ & 99 & 99 & 99 & 99 \\
\hline \multicolumn{2}{|c|}{ Encapsulated cell efficiency $(\%)$} & 14 & 17 & 20 & 14.1 \\
\hline \multicolumn{2}{|c|}{ Module life time (y) } & 30 & 40 & 50 & 30 \\
\hline
\end{tabular}

The balance-of-system defines the part of the PV power system other than the PV modules. The life cycle of the major BOS elements, which contribute significantly to the inputs and outputs of the entire system, is analyzed. These BOS elements are the inverters (including all the power conditioning electronics), the batteries and the foundations (Mason et al., 2006).

\subsection{Impact methodology}

Apart from PV-modules, all production procedures of inverters, batteries and steel foundations have been taken into account in evaluating the energy inputs and pollutant/emissions outputs, through EcoIndicator '95, as it is considered by experts to be diachronic and reliable when compared to other methodologies (Vogtländer et al., 2002). This model allows estimating the overall environmental impacts and the energy consumption from the manufacture of a certain product, taking into account not only the energy consumption and the impacts of final assembly, but also those from mining of metals, 
making electronic parts etc. (Demmers and Collignon, 1995). It is important to note that the aim is not to analyze and describe the life cycle procedures of the BOS components in detail within this paper, but to present total contribution per component to the life cycle of a PV-system. The main characteristics of the analyzed BOS-components in respect to the quantitative requirements for the case scenarios previously mentioned are presented on Table 2.

Table 2

Main characteristics and system requirements for the BOS-components.

\begin{tabular}{|c|c|c|c|}
\hline & Inver & ters & Batteries \\
\hline Power (kVA, kW) & \multicolumn{2}{|c|}{500} & 41.6 \\
\hline \multirow{4}{*}{$\begin{array}{l}\text { Number of } \\
\text { components' } \\
\text { replacements }\end{array}$} & Base case & 0 & Base case 2 \\
\hline & Improved case & 0 & Improved case \\
\hline & Forward case & 0 & Forward case \\
\hline & KC65T case & 0 & KC65T case \\
\hline Number of units & \multicolumn{2}{|c|}{2} & 520 \\
\hline \multirow[t]{2}{*}{$\begin{array}{l}\text { Life time of PV- } \\
\text { system (y) }\end{array}$} & $\begin{array}{l}\text { Base case: } \\
30\end{array}$ & $\begin{array}{c}\text { Improved case: } \\
40\end{array}$ & $\begin{array}{c}\text { Forward case: } \\
50\end{array}$ \\
\hline & \multicolumn{2}{|c|}{ Steel foundations } & \\
\hline Type of Steel & \multicolumn{2}{|c|}{$\begin{array}{l}\text { ECCS (Electrolytic } \\
\text { chrome coated steel) }\end{array}$} & \\
\hline \multirow{4}{*}{$\begin{array}{l}\text { Mass of Steel per } \\
\text { PV-installation }(\mathrm{kg})\end{array}$} & Base case & 57229 & \\
\hline & Improved case & 36159 & \\
\hline & Forward case & 30144 & \\
\hline & KC65T case & 65621 & \\
\hline
\end{tabular}

Evaluating data of Table 2, it comes out that two inverters are required during PV-system's life time for all case scenarios (SMA Solar Technology AG, 2013; Aixcon Powersystems, 2013). The installation of batteries is replaced every 10 years. This is a critical point for the study because batteries have a major effect on the system, so that the final results could change dramatically (Hoppecke Batterien, 2013). The mass of steel foundations is changed according to the number of PV-modules in the discerned PV-cases. The smaller the number of PV-modules, the smaller the mass of steel required for the construction of steel foundations.

The comparison of PV-systems with a conventional mode of electricity production (e.g. diesel unit) can be adequately done by the use of the LCA methodology (Fthenakis et al., 2009). The aim of this photovoltaic study is to determine the total set of greenhouse gas (GHG) emissions caused by the manufacture and operation of a large-scale Photovoltaic system. In order to present the advantages of PV-systems as electricity production units, a comparison of them with a conventional diesel power unit is made. The full scenario includes a large-scale solar photovoltaic system on the Greek island of Nisyros, which is currently supplied with electricity produced by the Diesel power units of the Dodecanese interconnected power system. Similar research (Alazraki and Haselip, 2007) has shown that similar projects are highly needed for securing power autonomy and, at the same time, environmental protection of distant locations from mainland of various countries.

The necessary calculations for the solar cells have been made on a square meter $\left(\mathrm{m}^{2}\right)$ unit solar cell area basis and for the secondary materials (aluminum, glass, EVA, Tedlar) on a per kg unit basis. All products or services have been represented as a system in the inventory analysis methodology. The functional unit in this study is the production of $1 \mathrm{kWh}$ of electricity. 
In the first row of Table 3 the total installed power of PV-systems for each of the assumed PV cases is shown, which in any case is close to $300 \mathrm{~kW}$. According to the total installed power and the maximum power of each PV-module the number of PV-modules, which is required for the PVinstallation, can be calculated. The number of PV-modules is determined by the energy requirements of the island which are estimated at $246050 \mathrm{kWh} / \mathrm{y}$, taking into account the increased energy consumption of summer season due to tourism inflows.

The energy of solar irradiation results from summation of the solar irradiation energies of all months of a year, taking place on Nisyros island. Furthermore, the intensity of solar radiation is a standard magnitude, which is equal to $1 \mathrm{~kW} / \mathrm{m}^{2}$ of module area, and is used for describing the technical characteristics of a PV-module. The overall operation ratio of PV-modules follows from the system ratio multiplied by the temperature correction factor $\mathrm{s}_{\mathrm{T}}$. This factor is equal to:

$$
\boldsymbol{S}_{T}=\frac{I_{T_{P V}}}{I_{T_{e}}}
$$

where $\mathrm{I}_{\mathrm{Tpv}}$ is the mean daily solar irradiation at the temperature of PV-module and $\mathrm{I}_{\mathrm{Te}}$ is the mean daily solar irradiation at the environmental temperature, per square meter of module area (Luque and Hegedus, 2011).

The produced DC energy from the PV-modules is obtained by multiplying the total installed power with the solar irradiation energy $\Pi_{\text {irr }}$, the annual mean of temperature correction factor $S_{\mathrm{T}}$ and the clearness factor $\mathrm{S}_{\mathrm{C}}$. The clearness factor is a measure of the fraction of the available sunlight that can pass through the glass of the module; dust and dirt can cause serious problems for the whole photovoltaic operation. Based on Balouktsis et al. (2006) stochastic time series model, a clearness factor distribution has been provided in order to finally reach a mean value to be used in total installed power calculations as presented in Table 3.

The next row of Table 3 provides the peripherals system ratio, which is the product of batteries ratio, inverters ratio and wiring ratio and is actually representing the efficiency of system components other than PV-modules. Finally, the produced AC energy is the result of multiplying the produced DC energy with the system ratio.

Table 3

Technical and energy characteristics of the hypothesized PV installations on Nisyros island.

\begin{tabular}{|c|c|c|c|c|c|c|}
\hline Parameter & Symbol & Unit & Base case & $\begin{array}{l}\text { Improved } \\
\text { case }\end{array}$ & $\begin{array}{c}\text { Forward } \\
\text { case }\end{array}$ & $\begin{array}{c}\text { KC65T } \\
\text { case }\end{array}$ \\
\hline Total installed power & $\mathrm{P}_{\text {inst }}$ & $\mathrm{kW}$ & 293.28 & 296.21 & 296.43 & 294.12 \\
\hline Number of PV-modules & $\mathrm{N}_{\text {final }}$ & - & 5104 & 2640 & 1640 & 4902 \\
\hline Total PV-module area & $\mathrm{A}_{\bmod }$ & $\mathrm{m}^{2}$ & 2246 & 1711 & 1640 & 2397 \\
\hline Solar irradiation energy & $\Pi_{\text {irr }}$ & $\mathrm{kWh} /\left(\mathrm{m}^{2} \cdot \mathrm{y}\right)$ & 1797 & 1797 & 1797 & 1797 \\
\hline $\begin{array}{l}\text { Intensity of solar radiation } \\
\text { (standard) }\end{array}$ & STC & $\mathrm{kW} / \mathrm{m}^{2}$ & 1 & 1 & 1 & 1 \\
\hline PV-modules system operation ratio & $\lambda_{\text {mod }}$ & - & 0.67 & 0.67 & 0.67 & 0.67 \\
\hline Temperature correction factor & $\mathrm{S}_{\mathrm{T}}$ & - & 0.91 & 0.91 & 0.91 & 0.91 \\
\hline Clearness factor & $\mathrm{S}_{\mathrm{C}}$ & - & 0.71 & 0.71 & 0.71 & 0.71 \\
\hline Produced energy DC & $\mathrm{E}_{\mathrm{DC}}$ & $\mathrm{kWh} / \mathrm{y}$ & 431929 & 436244 & 436568 & 433166 \\
\hline Peripherals system ratio & $\mathrm{a}$ & - & 0.735 & 0.735 & 0.735 & 0.735 \\
\hline Produced energy AC & $\mathrm{E}_{\mathrm{AC}}$ & $\mathrm{kWh} / \mathrm{y}$ & 317539 & 320711 & 320950 & 318449 \\
\hline $\begin{array}{l}\text { Electricity consumption on Nisyros } \\
\text { island }\end{array}$ & $\mathrm{E}_{\mathrm{Nis}}$ & $\mathrm{kWh} / \mathrm{y}$ & 246050 & 246050 & 246050 & 246050 \\
\hline
\end{tabular}


Table 4 provides a detailed view of final energy resources consumed for the production of PVmodules and BOS-components, corresponding to the case scenarios assumed. Improved photovoltaic production procedures that will be put in operation within the coming years will make possible a dramatic reduction of energy requirements for panels production. Moreover, annual power production, as well as electricity produced in PV-systems' estimated lifetime are included in Table 4. O.P.T. stands for Operational Period of Time and it denotes an estimation of the time an energy system will be at service. Since, PV installations do not release emissions during operational lifetime, the higher O.P.T. of the systems the better for their environmental profile. Improved and Forward case scenarios consider an increased O.P.T. for PV-systems as a result of producing better weather resistant and more reliable and serviceable system components in the future.

Table 4

Energy flows concerning various case scenarios of the hypothesized PV installations on Nisyros island.

\begin{tabular}{|c|c|c|c|c|c|c|c|c|c|}
\hline \multirow[t]{2}{*}{ Energy Flows } & \multirow[t]{2}{*}{ Unit } & \multicolumn{2}{|c|}{ Base Case } & \multicolumn{2}{|c|}{ Improved Case } & \multicolumn{2}{|c|}{ Forward Case } & \multicolumn{2}{|c|}{ KC65T case } \\
\hline & & Alum. $0 \%$ & Alum. $50 \%$ & Alum. $0 \%$ & Alum. $50 \%$ & Alum. $0 \%$ & Alum. $50 \%$ & Alum. $0 \%$ & Alum. $50 \%$ \\
\hline $\begin{array}{l}\text { Consumed Energy for PV- } \\
\text { modules production }\end{array}$ & GJ & 4946 & 4444 & 1387 & 1093 & 1151 & 947 & 4970 & 4500 \\
\hline $\begin{array}{l}\text { Consumed Energy for BOS- } \\
\text { components production }\end{array}$ & GJ & 4601 & 4601 & 4145 & 4145 & 5016 & 5016 & 5662 & 5662 \\
\hline Total Energy Consumption & GJ & 9547 & 9045 & 5532 & 5238 & 6167 & 5963 & 10632 & 10162 \\
\hline Annual Electricity Production & $\mathrm{GJ} / \mathrm{y}$ & 1143 & 1143 & 1155 & 1155 & 1156 & 1156 & 1147 & 1147 \\
\hline O.P.T. & $\mathrm{y}$ & 30 & 30 & 40 & 40 & 50 & 50 & 30 & 30 \\
\hline Produced Electricity in O.P.T. & GJ & 34290 & 34290 & 46200 & 46200 & 57800 & 57800 & 34410 & 34410 \\
\hline
\end{tabular}

A basic measure of the environmental profile of a product is the amount of $\mathrm{CO}_{2}$ that is released during its life cycle stages. First, estimated greenhouse emissions released to the environment during PV-components production procedures have been expressed in respect to the energy required to build them up and move them to the assembly site. This calculation is meaningful for assessing the environmental profile of production and management processes before putting PV-systems in operation. Next, same green gouse emissions have been expressed in respect to the electricity produced by the power systems. The latter is needed in order to assess the environmental profile of PV-systems while in operation. For evaluative reasons, this procedure has been repeated for the diesel power station and then it was compared to the various PV-systems cases, as presented in Table 5. A list of abbreviations is provided in Table 6 that is helpful for better examining Figures $5 \& 6$.

Figures $4,5 \& 6$ present graphically the overall $\mathrm{CO}_{2}$ equivalent emissions in g/O.P.T. (such as $\mathrm{CF}_{4}, \mathrm{SO}_{2}, \mathrm{NO}_{\mathrm{x}}, \mathrm{CH}_{4}$ ), the $\mathrm{CO}_{2}$ equivalent emissions in $\mathrm{g} / \mathrm{kWh}_{\mathrm{e}}$ electricity produced and the $\mathrm{CO}_{2}$ equivalent emissions in $\mathrm{g} / \mathrm{kWh}_{\mathrm{c}}$ of final energy source consumed (electricity), for the PV-system scenarios, as well as for the diesel power station that is currently in operation (GaBi Software, 2011; Eco-Indicator '95, 1999). 
Table 5

Carbon Dioxide equivalent emissions for the PV and Diesel case scenarios in respect to energy consumed and produced.

\begin{tabular}{lcc}
\hline PV - cases & $\mathbf{g ~ C O}_{\mathbf{2}} / \mathbf{k W h}$ & $\mathbf{g ~ C O} \mathbf{c} / \mathbf{k W h}$ \\
\cline { 2 - 3 } Base, alum.0\% & 6.09 & 54.82 \\
Base, alum.50\% & 6.04 & 51.68 \\
Improved, alum.0\% & 4.07 & 19.49 \\
Improved, alum.50\% & 3.99 & 18.11 \\
Forward, alum.0\% & 2.44 & 13.04 \\
Forward, alum.50\% & 2.38 & 12.28 \\
KC65T,alum.0\% & 6.34 & 58.81 \\
KC65T,alum.50\% & 6.31 & 55.89 \\
\hline Diesel power station & 144.6 & 921.8 \\
\hline
\end{tabular}

Table 6

\begin{tabular}{llc}
\multicolumn{3}{l}{ A List of abbreviations for PV-cases and Diesel scenarios. } \\
\hline PV-Case & Symbol & O.P.T., y \\
\hline Base-alum.0\%: & BC.0\% & 30 \\
Base-alum.50\%: & BC.50\% & 30 \\
Improved-alum.0\% & IC.0\% & 40 \\
Improved-alum.50\% & IC.50\% & 40 \\
Forward-alum.0\% & FC.0\% & 50 \\
Forward-alum.50\% & FC.50\% & 50 \\
KC65T-alum.0\% & KC65T.0\% & 30 \\
KC65T-alum.50\% & KC65T.50\% & 30 \\
Diesel power station & Diesel & $30,40,50$ \\
\hline
\end{tabular}

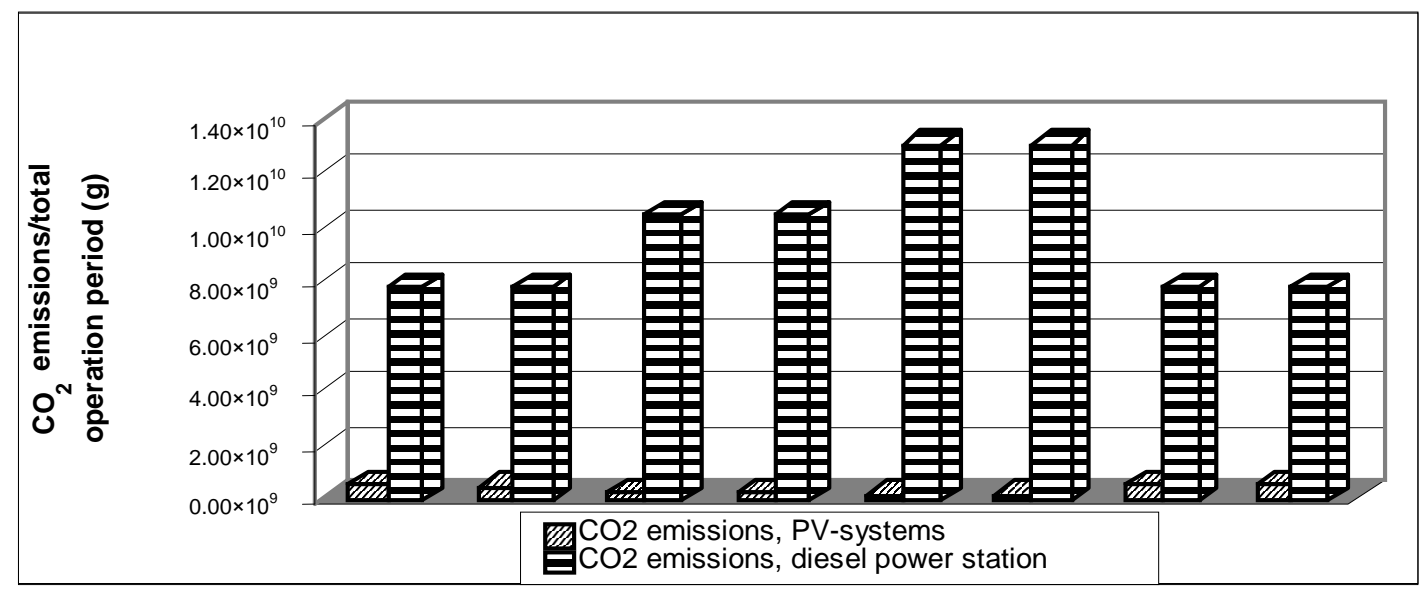

Fig. 4. Equivalent emissions of $\mathrm{CO}_{2}$ over PV-systems' lifetime and during the operational period of time of diesel power station. 


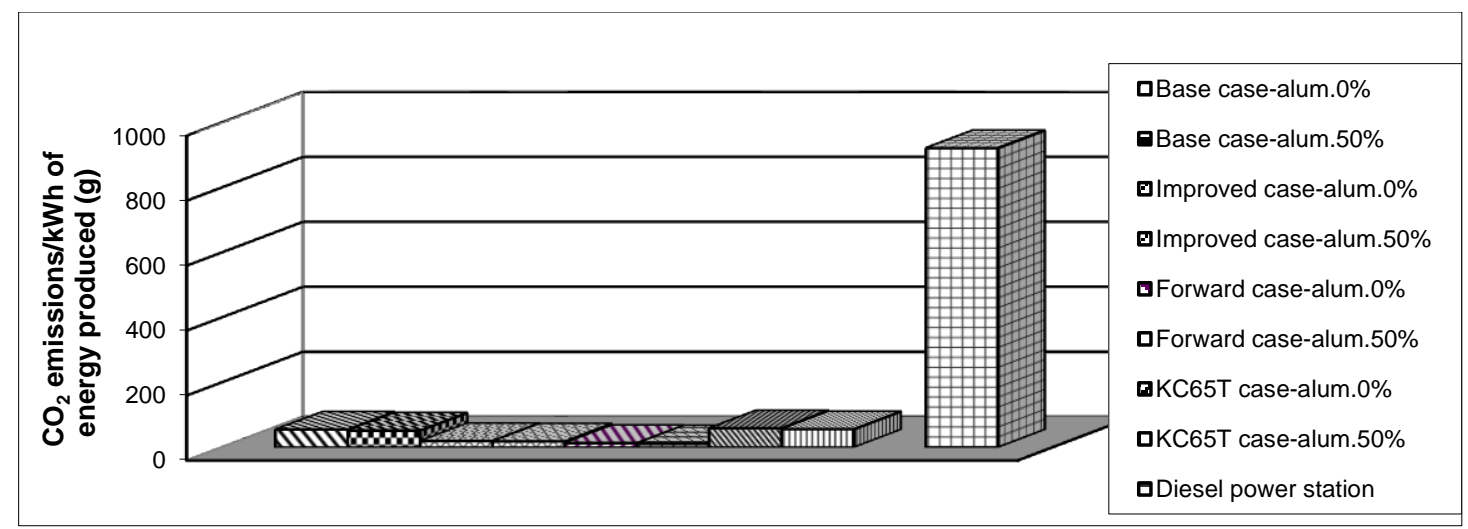

Fig.5. Equivalent emissions of $\mathrm{CO}_{2}$ per kWh of produced final energy for various $\mathrm{PV}$ case scenarios and diesel power station.

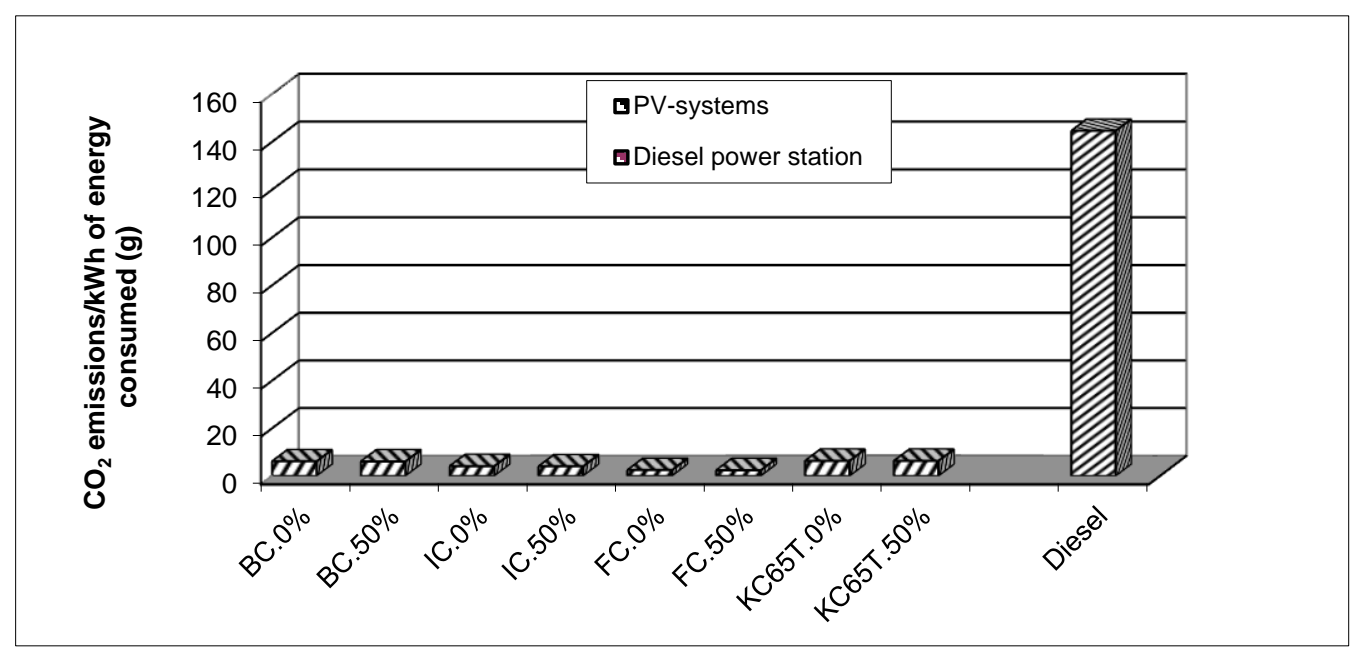

Fig.6. Equivalent emissions of $\mathrm{CO}_{2}$ per kWh of consumed final energy resource for various $\mathrm{PV}$ case scenarios and during the operational period of time of diesel power station.

\section{Results and Discussion}

In general, the differences between all the PV-cases and the diesel power station case are huge in $\mathrm{CO}_{2}$ diagrams (see Figs. 4, 5, 6). Differences of two orders of magnitude are noticed, which could substantially become greater if the construction of the diesel power station was taken into account. The 50\% aluminum recycle has a benefit indeed, but it cannot affect dramatically the whole PV-system. Perhaps, in case of a wider usage of recycling materials in all PV-components the benefits would be greater.

The comparison among the PV-cases does not present significant differences. The lowest $\mathrm{CO}_{2}$ equivalent emissions (in grams) are observed in the PV-forward cases (very close to zero). This is mainly due to the fact that for an almost equal total installed PV system power, among all PV cases, the Forward cases presume a significantly lower number of modules, that is $68 \%$ short in comparison to base cases and 38\% in comparison to improved cases. The cases that are based on the KC65T module provide us with similar results as those of base cases. O.P.T values (in years) do not affect the $\mathrm{CO}_{2}$ equivalent emissions of PV case scenarios, but only those of diesel power station. Apparently, this is due to the fact that there are no emissions during photovoltaic parks' operation, whereas emissions of 
diesel power station depend heavily on the operational time of power production facilities. As concerns the relative contribution of PV-modules and BOS-components in total carbon footprint estimate of PVsystems, it is concluded that in base and KC65T cases the contributions are about $70 \%$ and 30\%, respectively. Technological advances that are anticipated in the forthcoming years will help limiting dramatically not only the absolute total carbon footprint values, but also the relative contributions of the PV-system components, which have been estimated in this study to change to a $50 \%-50 \%$ analogy.

The uncertainty of the previous estimations stems from the corresponding uncertainty of the ecoinvent LCI databases (Ecoinvent, 2007). Variability and stochastic error have been treated in Ecoinvent v2.0 databases using lognormal distribution for all unit processes. However, application of Monte-Carlo simulation has provided probabilistic mean values for the flows that differ only slightly from the process raw data without use of the uncertainty factors. The ecoinvent research team supports that reliabililty of raw data mean values is much higher than that of statistical estimated values, and the reproducibility of the respective LCI results is a definite advantage. Therefore, it has been decided in the present study to apply the deterministic mean values instead of the probabilistic ones.

Comparing previous analysed PV parks case studies leads us to the conclusion that greenhouse gas emissions vary between 12.28 to $58.81 \mathrm{~g} \mathrm{CO}_{2} \mathrm{eq} / \mathrm{kWh}_{\mathrm{e}}$. For a better validation of these results, we have searched in international paper databases, and we found a series of geographically diverse publications that are summarized in Table 6 .

The study of Hondo (2005) provides similar to our KC65T case scenarios with a carbon footprint of $53.4 \mathrm{~g} \mathrm{CO}_{2} \mathrm{eq} / \mathrm{kWh}_{\mathrm{e}}$, since in both cases panels originate from Japan and the set of parameters are similar. The differences among the rest of the studies mentioned in Table 7 and the results of the present one (Table 6) could be attributed to variations in power scales, primary energy mixes, as well as module and overall system efficiencies. However, our main point here is not to compare and contrast the environmental profiles of various PV-systems. All PV-case scenarios of the present study, as well as similar studies conclude to carbon footprints that are certainly well below a ceiling of $104 \mathrm{~g}$ $\mathrm{CO}_{2} / \mathrm{kWh}_{\mathrm{e}}$, whereas the diesel power station at its best - taking into account only its operations stemming from power generation- provides an output emission of $921.80 \mathrm{~g} \mathrm{CO}_{2} / \mathrm{kWh}_{\mathrm{e}}$. Thus, PVsystems have clearly the potential to further lead to cleaner electricity production in contrast to conventional power generation systems.

Table 7

Recent studies of polycrystalline PV systems-Carbon Footprints in the international bibliography.

\begin{tabular}{cccccc}
\hline Year & Authors & Location & Power Rating & O.P.T., y & GHG emissions $\left(\mathbf{g ~ C O} \mathbf{C O}_{2} / \mathbf{k W h} \mathbf{h}_{\mathbf{e}}\right)$ \\
\hline 2008 & $\begin{array}{c}\text { Ito M, Kato K, Komoto K, } \\
\text { Kichimi T, Kurokava K. }\end{array}$ & China & $100 \mathrm{MW}$ & 30 & 12.1 \\
\hline 2007 & $\begin{array}{c}\text { Pacca S, Sivaraman D, } \\
\text { Keoleian G. A. }\end{array}$ & USA & $33 \mathrm{~kW}$ & 20 & 72.4 \\
\hline 2005 & Hondo H. & Japan & $3 \mathrm{~kW}$ & 30 & 53.4 \\
\hline 2005 & Battisti R, Corrado R. & Italy & $1 \mathrm{~kW}$ & 20 & 26.4 \\
\hline 2005 & $\begin{array}{c}\text { Tripanagnostopoulos Y, } \\
\text { Souliotis M, Battisti R, } \\
\text { Corrado A. }\end{array}$ & Greece & $3 \mathrm{~kW}$ & 20 & 104.0 \\
\hline
\end{tabular}




\section{Conclusions}

The present work revealed that concerns about air pollution stemming from PV-system components in all the life cycle stages of the system should be treated with caution. Greenhouse gas emissions for all the life cycle stages of the PV-components will be continuously decreasing with time due to the continuous improvement of production processes, especially in the areas of solar cells and panels manufacturing. Comparisons between conventional power generation unit using diesel oil and each of several PV-case system scenarios fully supported the PV-systems as being advantageous for cleaner electricity production. Previously published research with different PV-installation settings confirms a general global trend for a wide application of large-scale PV systems. A key determinant for ensuring further enhancement of PV-technologies in large-scale power generation is the introduction of the new solar cells manufacturing techniques in mass production. This will minimize energy and materials requirements and at the same time increase solar cells and PV-modules efficiency. Another important aspect is the operational period of time (O.P.T.) of PV-systems, which is actually determined by system reliability. An increased O.P.T. mitigates energy and raw material exploitation. Advanced manufacturing techniques extend the O.P.T. of large-scale PV-systems which is a major factor that makes PV-systems sustainable from both a financial and an environmental point of view.

\section{References}

Aixcon Powersystems 2013. www.aixcon.de/, last accessed on June 15, 2013.

Alazraki, R., \& Haselip, J. 2007. Assessing the uptake of small-scale photovoltaic electricity production in Argentina: the PERMER project. Journal of Cleaner Production 15(2), 131-142.

Alsema, E. A., Wild-Scholten, M.J., Fthenakis, V. M. 2006. Environmental Impacts of PV Electricity Generation - A critical comparison of energy supply options. In: Proceedings of 21th European Photovoltaic Solar Energy Conference. Dresden, Germany, 4-8 September 2006.

Alsema, E. A. 2000. Energy Payback time and $\mathrm{CO}_{2}$ emissions of PV systems, Progress in Photovoltaics: Research and Applications, 8, 17-25.

Aulich, H. A., \& Schulze, F.-W., 2002. Crystalline silicon feedstock for solar cells. Progress in Photovoltaics: Research and Applications 10, 141-147.

Balouktsis, A., Karapantsios, T. D., Antoniadis, A., Paschaloudis, D., Bezergiannidou, A., \& Bilalis, N. 2006. Sizing stand-alone photovoltaic systems. International Journal of Photoenergy, 2006, $1-8$.

Battisti, R., Corrado, R. 2005. Evaluation of technical improvements of photovoltaic systems through life cycle assessment methodology, Energy 30, 952-967.

Bernal-Agustín, J. L., \& Dufo-López, R. 2006. Economical and environmental analysis of grid connected photovoltaic systems in Spain. Renewable Energy 31(8), 1107-1128.

de Haes, H. A. U., Jolliet, O., Finnveden, G., Hauschild, M., Krewitt, W., \& Müller-Wenk, R. 1999. Best available practice regarding impact categories and category indicators in life cycle impact assessment. The International Journal of Life Cycle Assessment, 4(2), 66-74. 
Demmers, M., \& Collignon, M. (1995). The eco-indicator 95. M. Goedkoop (Ed.). Amersfoort (NL): PRé Consultants.

Du Pont, 2013. Tedlar polyvinyl fluoride film. www2.dupont.com/Tedlar_PVF_Film/en_US/ assets/downloads/pdf/h49725.pdf, last accessed on June 14, 2013.

Ecoinvent 2007. Overview and Methodology Data v2.0. Ecoinvent report No. 1. Swiss Centre for Life Cycle Inventories. Dübendorf, $\mathrm{CH}$.

Ecoinvent 2011. Final Ecoinvent v2.2 No. 3. Swiss Centre for Life Cycle Inventories. Dübendorf, CH.

Franklin Associates 2010. Cradle-To-Gate Life Cycle Inventory of nine plastic resins and four polyurethane precursors, Prairie Village, Kansas, 370 pp.

Fthenakis, V.M. et al., 2006. Evaluation of risks in the life cycle of photovoltaics in a comparative context. In: 21st European Photovoltaic Solar Energy Conference, Dresden, Germany.

Fthenakis, V.M., Kim, H.C., Alsema, E., 2008. Emissions from photovoltaic life cycles. Environmental Science \& Technology 42, 2168-2174.

Fthenakis, V. M., Kim, H. C., Held, M., Raugei, M., \& Krones, J. 2009. Update of PV Energy Payback Times and Life-Cycle Greenhouse Gas Emissions. 24th European Photovoltaic Solar Energy Conference, 21-25 September 2009, Hamburg, Germany.

GaBi Software 2011. www.gabi-software.com/databases/professional/, last accessed on June 15, 2013.

Green Design Initiative Economic Input-Output Life Cycle Assessment, Carnegie Mellon University 2013. www.eiolca.net/cgi-bin/dft/use.pl, last accessed on June 14, 2013.

Hischier, R., Weidema, B., Althaus, H.-J., Bauer, C., Doka, G., Dones, R., Frischknecht R., Hellweg S., Humbert S., Jungbluth, N., Köllner, T., Loerincik, Y., Margni, M., \& Nemecek, T. 2010. Implementation of Life Cycle Impact Assessment Methods. Final report ecoinvent v2.2 No. 3. Swiss Centre for Life Cycle Inventories. Dübendorf, $\mathrm{CH}$.

Hondo, H. 2005. Life cycle GHG emission analysis of power generation systems-Japanese case. Energy 30, 2042-2056.

Hoppecke Batterien, 2013. Hoppecke HOPzS, Stationary lead acid batteries. www.electricsystems.co.nz/documents/HOPzS-Brochure.pdf, last accessed on June 15, 2013.

Ito, M., Kato, K., Komoto, K., Kichimi, T., Kurokava, K. 2008. A comparative study on cost and lifecycle analysis for $100 \mathrm{MW}$ very large-scale (VLS-PV) systems in deserts using m-si, a-siCdTe and CIS modules. Progress in Photovoltaics Research and Applications 16, 17-30.

Jungbluth, N. 2005. Life cycle assessment of crystalline photovoltaics in the Swiss ecoinvent database. Progress in Photovoltaics Application and Research 13(5), 429- 446.

Jungbluth, N., Stucki, M., Frischknecht, R. 2009. Photovoltaics. In: Dones, R. et al., (editors), Sachbilanzen von Energiesystemen: Grundlagen für den ökologischen Vergleich von Energiesystemen und den Einbezug von Energiesystemen in ökobilanzen für die Schweiz. Ecoinvent report No.6 - XII, Swiss Centre for Life Cycle Inventories. Dübendorf, $\mathrm{CH}$.

Kyocera Corporation 2013. global.kyocera.com/, last accessed on June 15, 2013.

Luque, A., and Hegedus, S. (Eds.). 2011. Handbook of photovoltaic science and engineering. John Wiley \& Sons Ltd, West Sussex, UK.

Mason, J. E., Fthenakis, V. M., Hansen, T. \& Kim, H. C. 2006. Energy Payback and Life-cycle $\mathrm{CO}_{2}$ Emissions of the BOS in an Optimized 3.5 MW PV Installation. Progress in Photovoltaics: Research and Applications 14, $179-190$. 
Pacca S., Sivaraman, D., Keoleian, G.A. 2007. Parameters affecting the life cycle performance of PV technologies and systems. Energy Policy 35, 3316-3326.

Peng, J., Lu, L., Yang H. X. 2013. Review on life cycle assessment of energy payback and greenhouse gas emission of solar photovoltaic systems. Renewable and Sustainable Energy Reviews 19, 255 - 274.

Raugei M, Bargigli S, \& Ulgiati S. 2007a. Life cycle assessment and energy pay-back time of advanced photovoltaic modules: CdTe and CIS compared to poly-Si. Energy 32, 1310-1318.

Raugei, M. Frankl, P., Alsema, E., Wild-Scholten, M. Fthenakis, V., Kim, H. C. 2007b. Life Cycle Assessment of Present and Future Photovoltaic Systems. In: AIST Symposium Expectations and Advanced Technologies in Renewable Energy. Chiba, Japan.

Sherwani, A. F., Usmani, J. A., Varun, 2010. Life cycle assessment of solar PV based electricity generation systems: A review. Renewable and Sustainable Energy Reviews 14(1), 540-544.

Şengül, H., \& Theis, T. L. 2011. An environmental impact assessment of quantum dot photovoltaics (QDPV) from raw material acquisition through use. Journal of Cleaner Production 19(1), 21-31.

SMA Solar Technology AG 2013. files.sma.de/dl/15986/SC500MV-1600MV-DEN114310W.pdf, last accessed on June 14, 2013.

Stoppato, A. 2008. Life cycle assessment of photovoltaic electricity generation. Energy 33, 224- 232.

Swanson, R., 2006. A Vision for Crystalline Silicon Photovoltaics. Progress in Photovoltaics: Research and Applications, 14, 443-453.

Tripanagnostopoulos, Y., Souliotis, M., Battisti, R., Corrado, A. 2005. Energy, cost and LCA results of PV and hybrid PV/T solar systems. Progress in Photovoltaics Research and Applications 13, $235-250$.

Varun, Bhat, I. K., Prakash, R. 2009. LCA of renewable energy for electricity generation systems - A review. Renewable and Sustainable Energy Reviews 13, 1067-1073.

Vogtländer, J. G., Bijma, A., \& Brezet, H. C. 2002. Communicating the eco-efficiency of products and services by means of the eco-costs/value model. Journal of Cleaner Production, 10(1), 57-67. 